\author{
Military Technical College \\ Kobry El-Kobbah, \\ Cairo, Egypt
}

Proceedings of the $8^{\text {th }}$ ICCAE-8 Conference, 25-27 May, 2010

WR

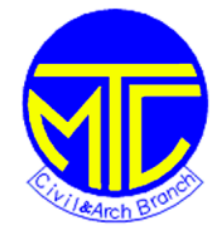
$8^{\text {th }}$ International Conference
$8^{\text {International Conference }}$ In Civil and Architecture
on
Engineering
ICCAE-8-2010

\title{
WATER BALANCE OF THE ASWAN HIGH DAM RESERVOIR TO SUSTAIN SEVERE FLOODS
}

\author{
By \\ WAEL KHADR ${ }^{1}$ AND M. EL-MOTASSEM KOTB ${ }^{2}$
}

\begin{abstract}
The operation of the Aswan High Dam is considered to be a very important and complicated issue. Its complication is due to different engineering and political rules that should be followed. This operation should manage the arriving water to the reservoir in order to sustain Egypt share in addition to the calculation of losses due to evaporation, seepage, and spill water. In a previously published research, based on probability analysis, the authors had proposed to raise the water level of the Aswan High Dam Reservoir on $1^{\text {st }}$ of August of each year to 178.00 meters above mean sea level instead of 175.00 meters that is currently applied. The reason for this recommendation is to sustain periods of low floods that might be similar to the drought periods that happened from year 1918 to year 1927 and from year 1978 to year 1987. They were also concluded that the maximum probable flood is about 125 Billion Cubic Meters per year.

In this research, Aswan High Dam Reservoir water balance model was developed, calibrated, verified, and used for predicting the reservoir balance under different high and severe flood conditions. Investigation of methods that can be used in order to apply this raise of level to 178.00 meters was performed. The operation rules of the reservoir under the proposed water level were also studied in cases of the reservoir full and different values of high and severe flood occurs.
\end{abstract}

KEYWORDS: Aswan High Dam Reservoir, Water Balance, Toshka Spillway, Natural River Nile Flow, Evaporation, Operation Rules.

\footnotetext{
1 Assistant Professor, Construction and Building Engineering Dept. Faculty of Engineering, Arab Academy for Science and Technology and Maritime Transport. Cairo, Egypt.

2 Emirate Professor, Nile Research Institute, National Water Research Center, Cairo, Egypt.
} 


\section{INTRODUCTION}

The Aswan High Dam Reservoir (AHDR) is located across the Egyptian Sudanese border. It extends from latitude $20^{\circ} 27^{\prime} 00^{\prime \prime} \mathrm{N}$ to latitude $23^{\circ} 58^{\prime} 00^{\prime \prime} \mathrm{N}$ and from longitude $30^{\circ} 07^{\prime} 00^{\prime \prime} \mathrm{E}$ to longitude $33^{\circ} 15^{\prime} 00^{\prime \prime} \mathrm{E}$. The reservoir length is $500 \mathrm{~km}$ along the Nile River and it covers an area of $6,000 \mathrm{~km}^{2}$. The Reservoir can be divided into two parts, the northern part, which is about two-thirds of reservoir length, located in Egypt and it is known as Lake Nasser. The southern part, which is about one-third of reservoir length, located in Sudan and it is called Lake Nubia. According to the design of the Aswan High Dam and to the agreement between Egypt and Sudan in 1959, the maximum water level of the reservoir is 182.00 meters above mean sea level which corresponds to 162.3 Billion Cubic Meters (BCM) of water stored in the reservoir [9]. During the construction of the dam, its operation rules was set to define the water level on $1^{\text {st }}$ of August of any year to be 175.00 meters above mean sea level which corresponds to $121.3 \mathrm{BCM}$ of stored water. Figure 1 shows sketch map of the Aswan High Dam Reservoir [3].

In order to satisfy the safety conditions of the dam, two spillways were

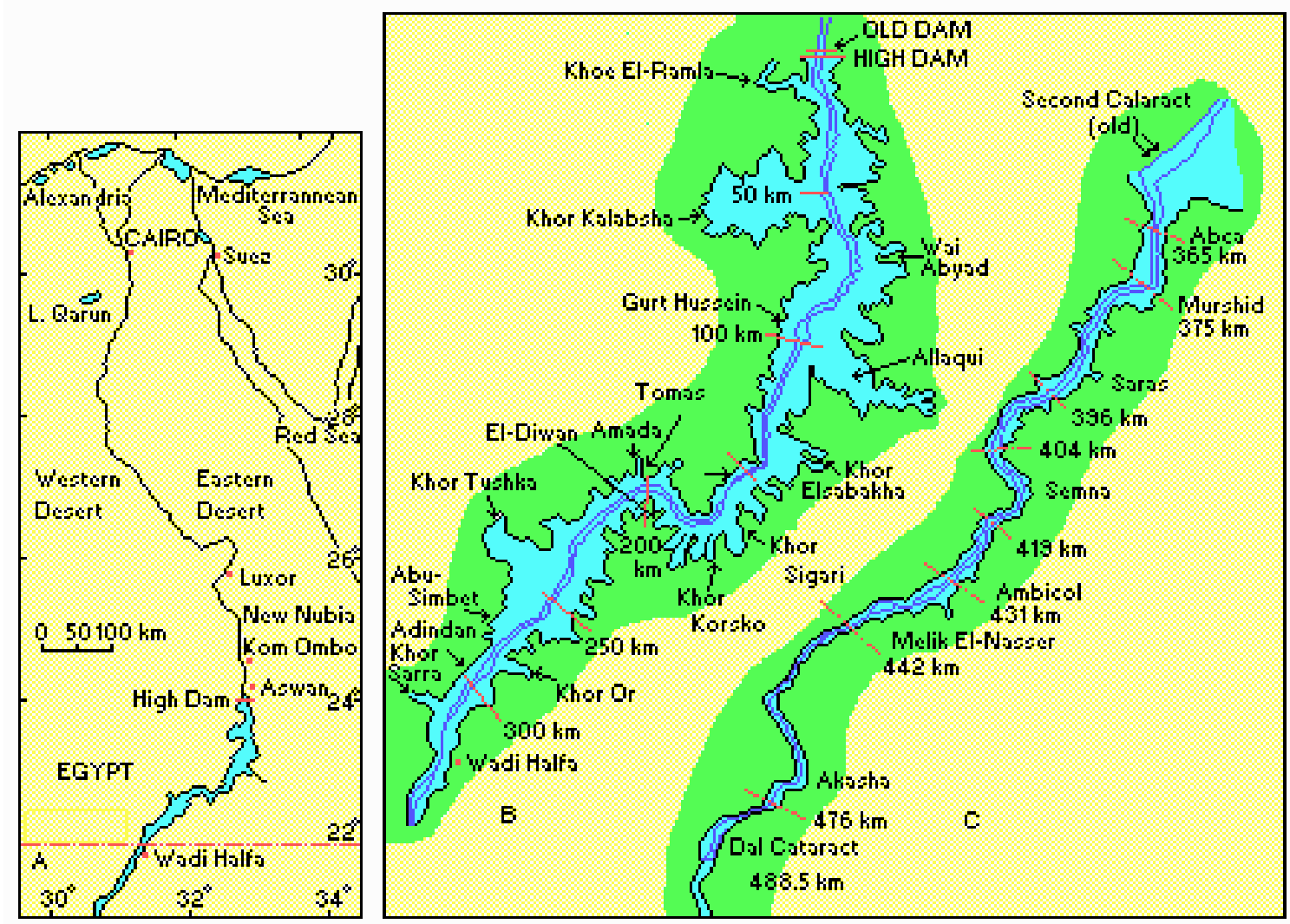

Figure 1: Sketch map of Aswan High Dam Reservoir [3].

constructed. The first one located at Aswan on the west diversion channel of the river beside the High Dam. This spillway is controlled by radial gates and spills 
water above level 178.00 meters into the River Nile downstream of the High Dam. The second spillway was constructed in 1976 at Khor Toshka to spill excess water to Toshka depression through a 22 kilometer length man made channel started and ended with two weirs. This spillway is designed and constructed as uncontrolled spillway and it spills water above level 178.00 meters uncontrolled to the depression. In addition to the two spillways, water can go out of the reservoir through 6 tunnels in the hydropower station either through the turbines or bypassing them. Water goes out of the hydropower station is controlled by the tunnels gates and it flows to the River Nile downstream of the High Dam.

During the periods of 1918 to 1927 and 1978 to 1987, the river Nile basin suffered from drought that caused a human disaster. During these two periods, the major problem initiated not only because of the low floods during that period but also because of the long period of the drought (10 years for each period). In a previous research [5], the authors had studied the statistics of natural river flood in order to calculate the deficit of water during any coming drought period. Bases on the probability analysis, they concluded that the maximum number of years during a drought period is expected to be 10 years and that will cause a deficit of water of $101.5 \mathrm{BCM}$. They recommended raising the water level upstream the Aswan High Dam level into 178.00 meter on $1^{\text {st }}$ of August in any year to sustain that probable drought period. They concluded also that the maximum probable natural river flood is $125 \mathrm{BCM}$.

As the application of this water level rising may cause problems for years of high floods if the reservoir is full, a comprehensive research is conducted and presented hereafter in order to assess the capability of the AHDR to sustain high floods under the condition that the reservoir is full. Reservoir balance model based on the conservation of mass was developed, calibrated verified and used for future prediction. Data for different items of water balance such as Egyptian share, Sudanese share, evaporation, seepage, regional flow, and bank storage were collected, inspected and used for the model. A relationship between water discharged to Toshka spillway and the reservoir water level in addition to a relationship between the bank storage and the reservoir water level are presented. Different alternatives were studied in order to sustain the two constraints of water level on $1^{\text {st }}$ of August is 178.00 meters and the maximum water level is 182.00 meters for different values of natural river flood.

\section{MODEL DESCRIPTION}

In order to calculate the required reservoir capacity and to define the Aswan High Dam operation rules prior to the construction of the dam, Hurst et.al. [4] used a simple reservoir balance equation based on the conservation of the mass. This equation was applied on monthly basis as follows:

$V_{2}=V_{1}+I-O_{E}-O_{S}-E$ 
Where:

$V_{2}$ and $V_{1}$ are the contents of the reservoir at end and the beginning of any time period respectively,

$I$ is the natural river flows during the time period,

$O_{E}$ and $O_{S}$ are the Egyptian and the Sudanese share during the time period respectively, and

$E$ is the evaporation during the time period.

Emam [1] used a formula after the Master Plan [7] who modified the model developed by Hurst et.al. and constructed similar monthly mean simulation model for the Aswan High Dam Reservoir (AHDR) in the form of:

$V_{2}=V_{1}+I-O_{E}-O_{S}-E-S-\Delta B-T$

Where:

$S$ is the regional through flow,

$\Delta B$ is the change in bank storage,

$T$ is the volume of water spilled to Toshka depression, and

$V_{2}, V_{l}, I, O_{E}, O_{S}$, and $E$ are as above.

During the course of this research, the authors used the same model developed by Hurst et.al. [4] and modified by Master Plan [7] explained before with slight modification to add a new term $A$ to represent the water spilled from the hydropower station in access of the Egyptian share because of dam safety. Since the term $\mathrm{S}$ and the term $\Delta B$ in equation 2 were found to have very small values that were found not to affect the results, they were combined with the seepage in one term called $\Delta S$. The model was applied on daily basis and can be represented by the following equation:

$V_{2}=V_{1}+I-O_{E}-O_{S}-E-\Delta S-T-A$

Where:

$A$ is the water spilled from Aswan in access of the Egyptian share, and $\Delta S$ is the seepage, regional through flow, and change in bank storage.

\section{DATA DESCRIPTION}

In order to construct the model required to satisfy the objective of this research, data from several sources were collected, inspected, and used. Since the aim of this research is to perform water balance of the High Aswan Dam Reservoir under reservoir full condition with severe flood, only historical data for the years of reservoir full or near full conditions were used to construct the model. These years were found to be four water years starting on $1^{\text {st }}$ of August 1998 and ended on $31^{\text {st }}$ of July 2002. The data was divided into two groups, first group consists of three years from $1^{\text {st }}$ of August 1998 to $31^{\text {st }}$ of July 2001 and used for model calibration. On the other hand, the second group of data consists 
only of one year from $1^{\text {st }}$ of August 2001 to $31^{\text {st }}$ of July 2002 and used for model verification. Although more data are available, it has not been used since it does not represent reservoir full or near full conditions.

\subsection{Reservoir level, area, and volume}

Daily water levels of the Aswan High Dam Reservoir were obtained for the study period (calibration and verification period). Using the Level-AreaContents table of the reservoir provided by many researchers [9 and 4] daily water surface area and water contents of the reservoir can be obtained. Both daily water surface area and monthly mean evaporation described below were then used to calculate the daily evaporation volume. Figure 2 shows the daily water levels upstream Aswan High Dam for both calibration and verification periods.

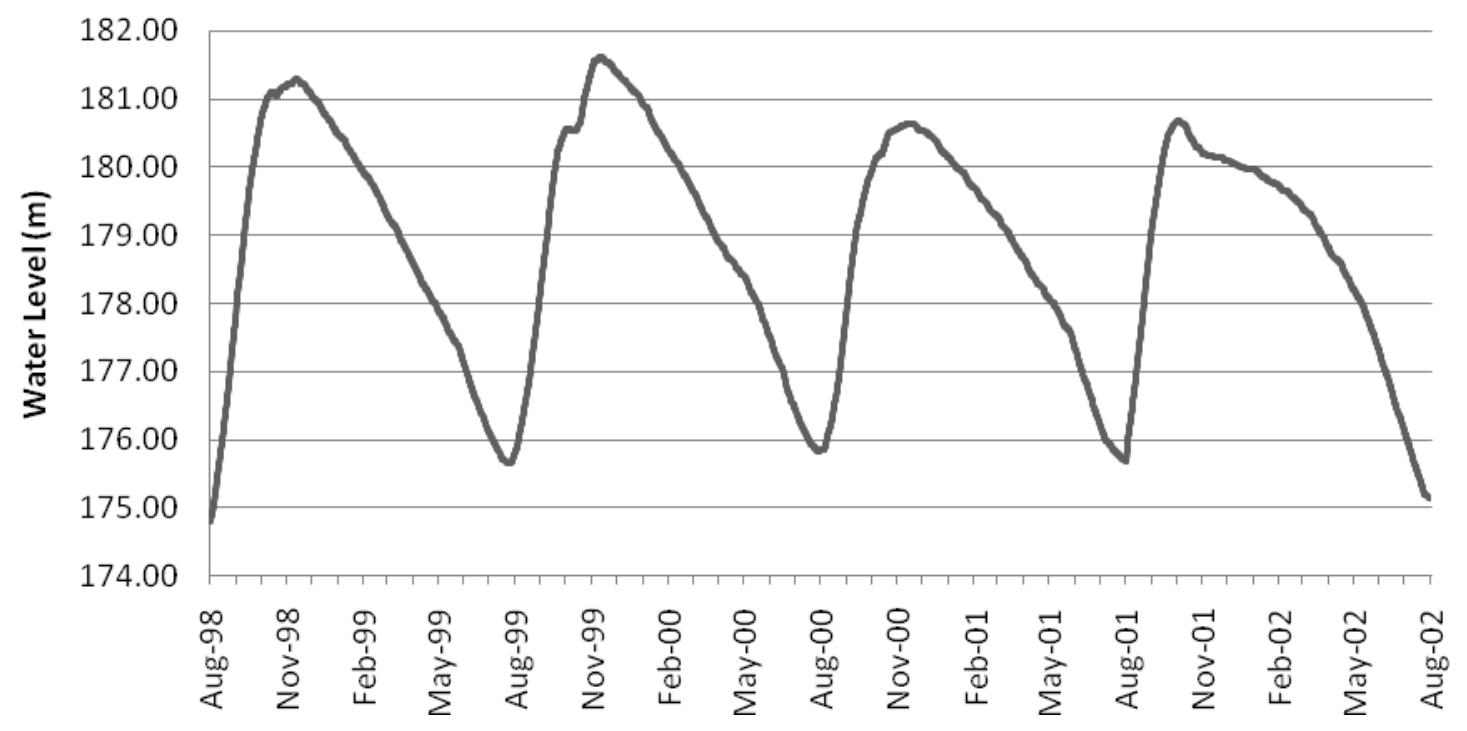

Figure 2: Daily water levels upstream Aswan High Dam from August 1998 to July 2002.

\subsection{Evaporation}

The Aswan High Dam Reservoir is located in a hot and extremely arid climate region. As a result, the evaporation losses represent the major water loss. Since the reservoir has highly irregular configurations surrounded by rugged area, then the evaporation is difficult to measure with high accuracy. Monthly mean evaporation rates are available at Aswan and Wadi Halfa [4]. In addition the High Aswan Dam Authority had installed a manually operated floating station at Aswan in addition to many other stations that form a network. Data of these floating stations was then interpreted by a joint project between the Nile Research Institute and the Academy of Scientific Research and Technology to 
calculate the Monthly mean average evaporation as a function of month of the year and the water level in the AHDR.

\subsection{Natural river flows and Sudanese share}

Since the natural river flows and the Sudanese share were not available on daily bases, monthly values were obtained for the same periods of calibration and verification. Applying the interpolation technique, daily values of both natural river flow and the Sudanese share were interpolated conserving the monthly mean and annual values for the interpolated data equal to the measured monthly mean and measures annual values. Figure 3 shows a comparison between the monthly mean values and the interpolated daily values of the natural river flow from August 1998 to July 2002.

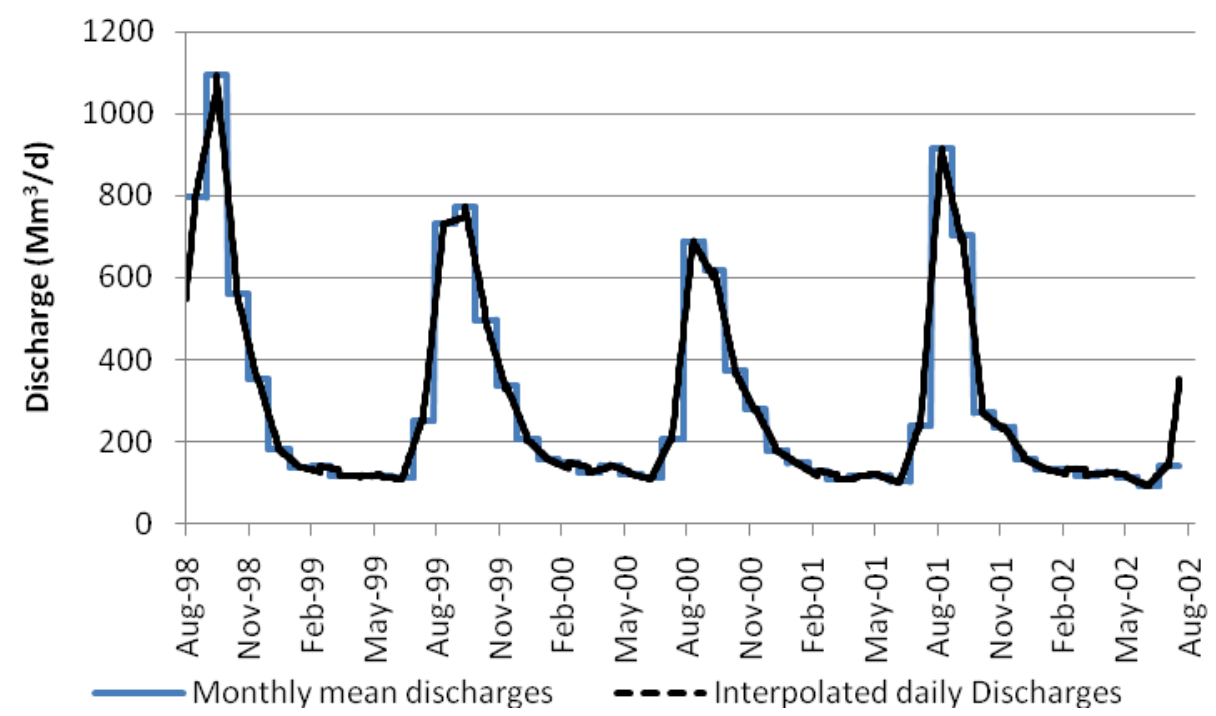

Figure 3: Comparison between the monthly mean values and the interpolated daily values of the natural river flow from August 1998 to July 2002.

\subsection{Releases from Aswan High Dam}

Daily releases for the Aswan High Dam (AHD) are available for the study periods of calibration and verification. During these periods, no spill water was released from the western spillway in the western diversion channel. On the other hand, discharges more than Egyptian share were released from the hydropower station for the dam safety. The daily spill water from the hydropower station was separated from the dam release by subtracting the daily Egyptian share from the daily actual AHD release. The annual Egyptian share, annual hydropower station spilled water, and the annual total releases from AHD were calculated from the daily values and are shown in Table 1. Figure 4 shows the daily Egyptian share, the daily spilled water from the hydropower station, and the daily total releases from the Dam. 
Table 1: Annual Egyptian share, annual hydropower station spilled water, and the annual total releases from AHD

\begin{tabular}{|l|c|c|c|c|}
\hline & $1998-1999$ & $1999-2000$ & $2000-2001$ & $2001-2002$ \\
\hline Egypt share (BCM/y) & 55500 & 55500 & 55500 & 55500 \\
\hline Hydropower spill water (BCM/y) & 15935 & 11555 & 6475 & 12625 \\
\hline Total releases from AHD (BCM/y) & 71435 & 67055 & 61975 & 68125 \\
\hline
\end{tabular}

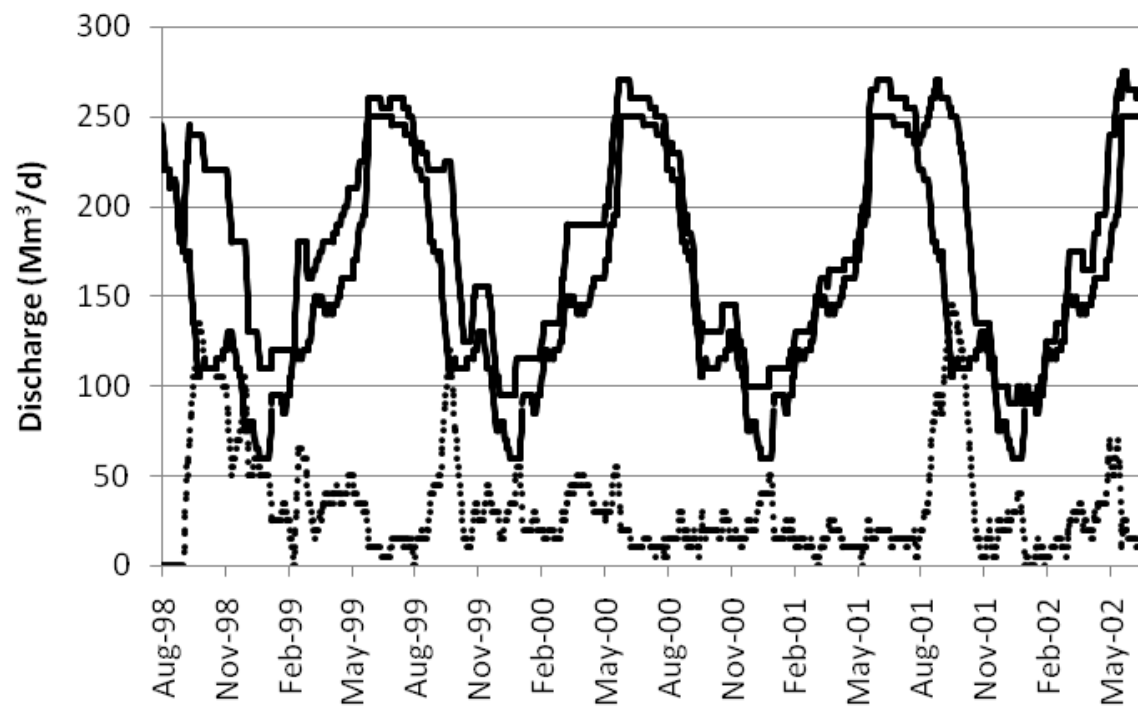

- Egyptian share ....... AHD spilled water —_ Total releases from AHD

Figure 4: Egyptian share, the spilled water from the hydropower station, and the total releases from the Dam.

\subsection{Toshka spill water}

Daily discharges to Toshka depression are available for the study periods of calibration and verification. As explained before, water goes to Toshka depression from Khor Toshka through $22 \mathrm{~km}$ man made channel started and ended with two weirs. During 1998/1999 and 1999/2000, water was discharged into the depression uncontrolled if the water level of the reservoir is above 178.00 meters. In 2000/2001 and 2001/2002, Egypt constructed an earth fill dam above the spillway to control the releases to Toshka depression. Many researchers had developed a level-discharge relationship for the Toshka spillway. Emam [1] used a form of

$T=\beta *\left(H-H_{o t}\right) * \gamma * 30.4 * 10^{-3}$

Where $\beta=19, \gamma=1.667, H$ is AHDR level, $H_{o t}$ is the threshold level = 178.0

Mostafa [8] developed a form of

$Q=22.8 *(\text { Level }-178)^{1.6475}$ 
Where $\mathrm{Q}$ is the discharge in $\mathrm{Mm}^{3} / \mathrm{d}$ to Toshka Depression and Level is the AHDR Level.

He reported that the High Aswan Dam Authority [2] developed in 1976 a theoretical form that was not calibrated on that time against real discharges as follows:

$Q=19 *(\text { Level }-178)^{5 / 3}$

\section{MODEL CALIBRATION AND VERIFICATION}

In order to use the water balance model presented in equation 3 to manage the water distribution in the High Aswan Dam Reservoir, a calibration of the model is required to determine the model unknown $\Delta s$ as a function of the water level. Although the discharges to Toshka depression were measured during the calibration and verification period, a relationship between this discharge and the water level was developed in order to use it in the model prediction.

\subsection{Toshka spill water}

In order to predict the quantities of water released to Toshka spillway, a level discharge relationship is required. The authors tried out the formula presented in equation 4 and they found that the disadvantage of it is that it considers the relationship between the level and the discharge is linear while it is not. The Authors have developed a form for the Toshka spill water based on the theoretical formula of the Ogee weir [6] neglecting the approaching velocity as follows:

$\mathrm{T}=\mathrm{C}_{\mathrm{w}} * \mathrm{~L} *\left(\mathrm{H}-\mathrm{H}_{\mathrm{ot}}\right)^{(3 / 2)} * \frac{(24 * 60 * 60)}{10^{6}}$

Where $L$ is the weir length $=750$ meters, $C_{w}$ was obtained by regression of the actual discharges and water levels for calibration period and found to be 0.2734 . Figure 5 shows two charts to compare the measured and the calculated discharges of Toshka spillway. It can be seen from the two charts that good agreement between the calculated and the measured was obtained during the years 1998/1999 and 1999/2000. In 2000/2001 and due to the manual control of the water going to the Toshka spillway, by adding the earthfill small dam above the weir to prevent the water from going to the depression unless the level is above 179.00 meters, the relationship presented in equation 7 fails to predict the calculated discharges that comply with the actual discharges. This failure was expected since there is no formula can predict manual controlled phenomena. As a result, no verification of the formula will be performed since the Toshka releases were also controlled in verification period 2001/2002. 


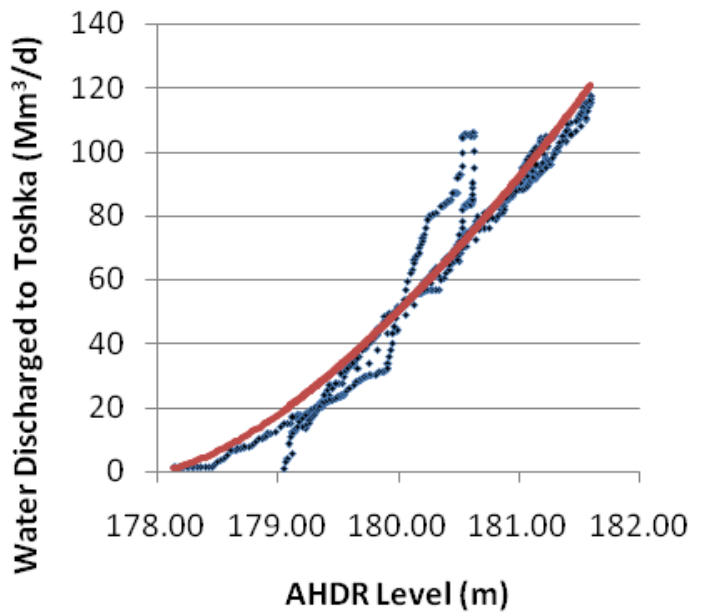

- Measured Calculated

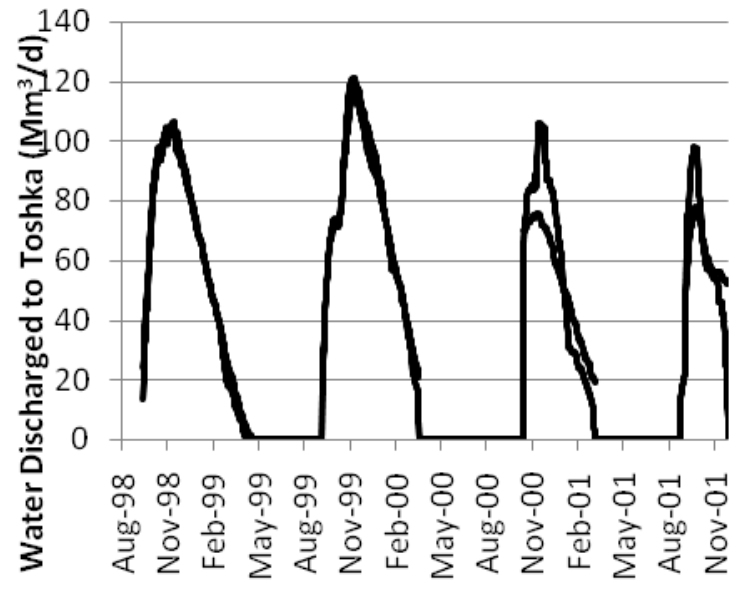

Date

Measured - - - Calcullated

Figure 5: Comparison between the measured and the calculated discharges of Toshka spillway.

\subsection{Change in bank storage}

As explained before, the regional through, change in bank storage and seepage were combined in one variable called $\Delta S$. During Calibration and verification periods, actual measurements of the Toshka releases were used since it provides higher accuracy in the model. The variable $\Delta S$ was calculated using equation 3 on daily bases by adjusting the daily calculated water level to be equal to the daily measured water level. The values of $\Delta S$ were then fitted against the AHDR level. It was found that the equation provided by Emam [1] is good enough to represent the data. This formula could be written as follows:

$\Delta \mathrm{S}=\mathrm{n} * \mathrm{~A} *\left(\frac{\left(\mathrm{H}-\mathrm{H}_{\mathrm{ot}}\right)}{2}-120\right)$

The coefficient of determination $\left(R^{2}\right)$ values for the calibration and verification periods were 0.91 and 0.86 respectively. Although low values of the $R^{2}$ were obtained, the equation is still considered to be applicable since the value of $\Delta S$ is small compared to other variable of water balance.

\section{MODEL ASSUMPTIONS}

As described before, the objective of this research is to assess the capability of the AHDR to sustain high floods under the condition that the reservoir is full. Since the authors proposed in a previous research [5] to raise the water level on $1^{\text {st }}$ of August to 178.00 meters, this research will investigate the effect of different water levels on $1^{\text {st }}$ of August on the flood resistance capability of the reservoir. After calibrating and verifying the model of equation 3, it has been used for AHDR water balance with the following assumption: 
- Different water levels on $1^{\text {st }}$ of August were tried out. These water levels range from 175.00 meters to 178.00 with increment 0.5 meters.

- The maximum water level on any day of the year should not be higher than 182.00 meters for dam safety.

- Different scenarios of natural river flow (X BCM) ranges from $105 \mathrm{BCM}$ to $125 \mathrm{BCM}$ with $5 \mathrm{BCM}$ increment were used. Measured natural river flow in the year $1998 / 1999$ that has a total of 120.855 BCM, was multiplied by a factor of $(\mathrm{X} / 120.855)$. This assumes that the natural river flow will have the same daily distribution as in the year 1998/1999 with a total of X BCM.

- Egyptian share is constant as $55.5 \mathrm{BCM} / \mathrm{y}$.

- Measured Sudanese share available in the year 1998/1999, that has a total of 13.2 BCM, was magnified by a factor of (18.5/13.2). This assumes that the Sudanese share will have the same distribution as measured in the year $1998 / 1999$ with a total of 18.5 BCM which is the Sudanese share in the 1959 agreement.

- Same evaporation function of water level and monthly evaporation were used as calibration and verification period.

- Same regional flow function presented in equation 8, which was calibrated and verified, was used.

- Aswan Spill water has an advantage of washing the Nile river bed downstream from Aswan. It has also a disadvantage of covering some low levees of the river that is currently used by people. As a result, different scenarios of annual Aswan spill water were used. These scenarios are 0 $\mathrm{BCM}, 8 \mathrm{BCM}$, and $16 \mathrm{BCM}$ that represent $0 \%, 50 \%$, and $100 \%$ of the Aswan spill water during 1998/1999. These values of spill water were assumed to have the same distribution pattern as year 1998/1999. This year was selected since it has the maximum historical Aswan spill water.

- Different scenarios of Toshka spill water were used. These scenarios represent uncontrolled conditions of the existing weir. In addition, the tried scenarios represent replacing the existing weir with a barrage and increasing the 22 kilometer man made channel conveyance capacity.

\section{MODEL RESULTS}

Applying the above assumptions for the case of the uncontrolled weir of Toshka spill water represented in equation 7 , the maximum allowable natural river floods that will assure maximum AHDR water level of 182.00 were determined for different values of AHDR level on $1^{\text {st }}$ of August and different values of annual Aswan spill water as shown in table 2 and figure 6. From the table and the figure, it can be seen that in order to assure a maximum of AHDR level of 182.00 and having no spill water at Aswan, the maximum allowable 
natural river flood that the reservoir can sustain is $117.2 \mathrm{BCM}$ and $93.5 \mathrm{BCM}$ for water level on $1^{\text {st }}$ of August 175.00 meters and 178.00 meters respectively. In case of having annual Aswan spill water equal to $16 \mathrm{BCM}$, the maximum allowable natural river flood that the reservoir can sustain is $128.8 \mathrm{BCM}$ and 103.3 $\mathrm{BCM}$ for water level on $1^{\text {st }}$ of August 175.00 meters and 178.00 meters respectively.

Based on the results presented in table 2, it can be concluded that if AHDR level on $1^{\text {st }}$ of August is raised to 178.00 meters, the Toshka spillway cannot be operated as uncontrolled weir since it will only sustain 103.3 BCM while the maximum probable flood is $125 \mathrm{BCM}$ and also it allows water to spill to the depression uncontrolled and this will cause AHDR level on $31^{\text {st }}$ of July to be 174.74 meters which is below 178.00 required for the following year.

Table 2: Maximum allowable natural river flood for different level on $1^{\text {st }}$ of August and different values of Aswan spill water. Case of uncontrolled weir.

\begin{tabular}{|c|c|c|c|c|c|c|c|c|c|}
\hline \multirow{2}{*}{$\begin{array}{l}\text { Level } \\
\text { on } 1^{\text {st }} \\
\text { of } \\
\text { August }\end{array}$} & \multicolumn{3}{|c|}{$\begin{array}{c}16 \text { BCM } \\
\text { Annual Aswan spill water }\end{array}$} & \multicolumn{3}{|c|}{$\begin{array}{c}8 \mathrm{BCM} \\
\text { Annual of Aswan spill water }\end{array}$} & \multicolumn{3}{|c|}{$\begin{array}{c}0 \mathrm{BCM} \\
\text { Annual Aswan spill water }\end{array}$} \\
\hline & $\begin{array}{l}\text { Level } \\
\text { on } 31^{\text {st }} \\
\text { of July }\end{array}$ & $\begin{array}{c}\text { Allowable } \\
\text { Flood } \\
\text { Value }\end{array}$ & $\begin{array}{c}\text { Annual } \\
\text { Toshka } \\
\text { Spill } \\
\text { Water }\end{array}$ & $\begin{array}{l}\text { Level } \\
\text { on } 31^{\text {st }} \\
\text { of July }\end{array}$ & $\begin{array}{c}\text { Allowable } \\
\text { Flood } \\
\text { Value }\end{array}$ & $\begin{array}{c}\text { Annual } \\
\text { Toshka } \\
\text { Spill } \\
\text { Water }\end{array}$ & $\begin{array}{l}\text { Level } \\
\text { on } 31^{\text {st }} \\
\text { of July }\end{array}$ & $\begin{array}{c}\text { Allowable } \\
\text { Flood } \\
\text { Value }\end{array}$ & $\begin{array}{c}\text { Annual } \\
\text { Toshka } \\
\text { Spill } \\
\text { Water }\end{array}$ \\
\hline meters & meters & $\mathrm{BCM}$ & BCM & meters & $\mathrm{BCM}$ & $\mathrm{BCM}$ & meters & $\mathrm{BCM}$ & $\mathrm{BCM}$ \\
\hline 178.00 & 174.64 & 103.3 & 16.9 & 175.06 & 98.6 & 17.9 & 175.42 & 93.5 & 18.8 \\
\hline 177.50 & 174.92 & 107.8 & 17.1 & 175.31 & 102.9 & 18.0 & 175.65 & 97.6 & 18.9 \\
\hline 177.00 & 175.19 & 112.2 & 17.3 & 175.55 & 107.2 & 18.2 & 175.86 & 101.7 & 19.1 \\
\hline 176.50 & 175.45 & 116.6 & 17.6 & 175.78 & 111.3 & 18.4 & 176.07 & 105.7 & 19.2 \\
\hline 176.00 & 175.68 & 120.7 & 17.8 & 176.00 & 115.3 & 18.6 & 176.26 & 109.6 & 19.4 \\
\hline 175.50 & 175.91 & 124.8 & 18.1 & 176.20 & 119.3 & 18.9 & 176.45 & 113.5 & 19.6 \\
\hline 175.00 & 176.12 & 128.8 & 18.3 & 176.39 & 123.1 & 19.1 & 176.63 & 117.2 & 19.8 \\
\hline
\end{tabular}




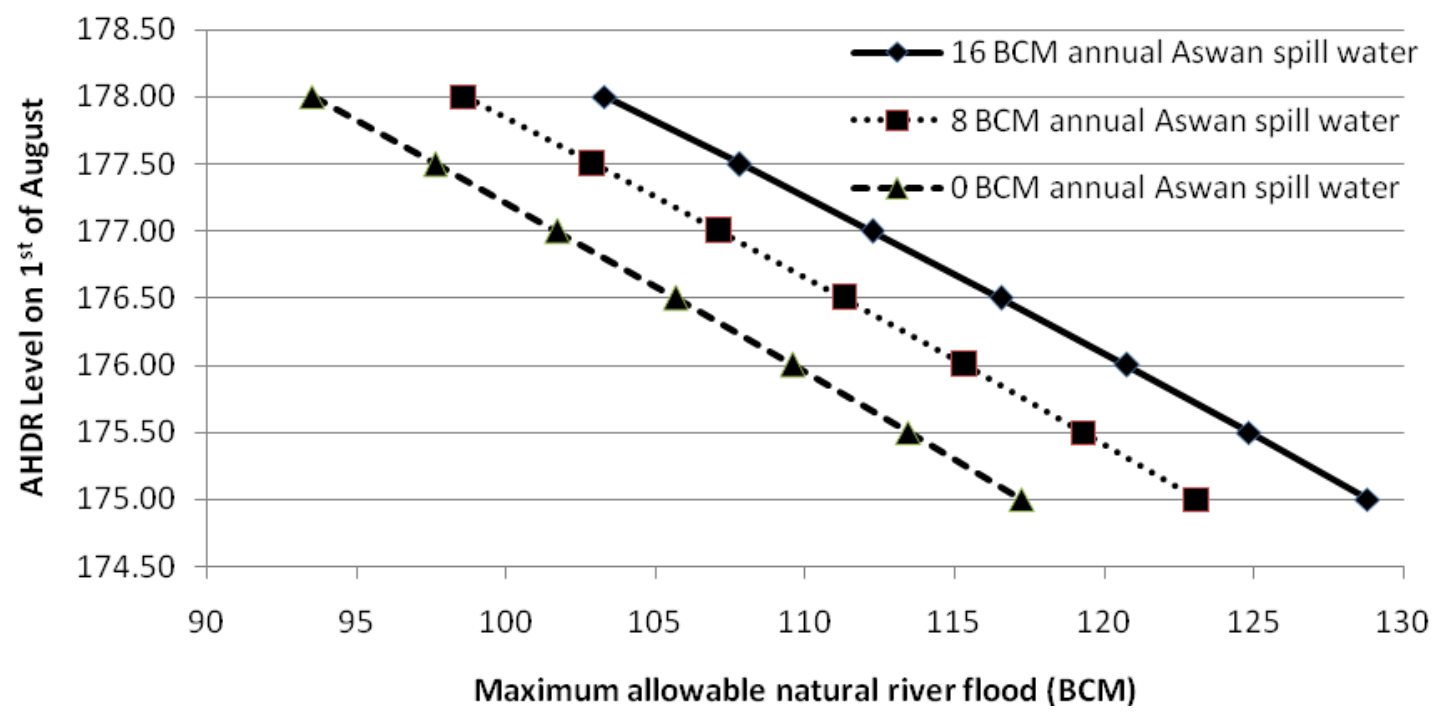

Figure 6 : Maximum allowable natural river flood for different level on $1^{\text {st }}$ of August and different values of Aswan spill water. Case of uncontrolled weir.

Since the Ministry of Water Resources and Irrigation is currently studying replacing the Toshka weir with a barrage, AHDR water balance was performed with barrage alternative. An optimization of equation 3 was performed having two constrains, which are Maximum AHDR level is 182.00 meters and AHDR level on $31^{\text {st }}$ of July (at the end of the year) is equal to AHDR level on $1^{\text {st }}$ of August (at the begging of the year). This optimization was performed assuming that the barrage will be closed during August until the natural river flood is predicted, on $1^{\text {st }}$ of September, it will be controlled to pass required discharges for certain number of days, then it will be closed till the end of the year $\left(31^{\mathrm{st}}\right.$ of July). The optimization is repeated assuming different values of AHDR level on $1^{\text {st }}$ of August, different values for annual Aswan spill water, and different values of natural river flood. The output of this optimization is the number of days required to operate the barrage starting from $1^{\text {st }}$ of September and the discharge that is expected to pass through the barrage for each scenario.

Figure 7 shows a relationship between the AHDR level on $1^{\text {st }}$ of August and the discharge expected to pass through the proposed Toshka barrage for different values of natural river flood in case of annual Aswan spill water equal to $16 \mathrm{BCM}$. Figure 8 and figure 9 are similar to figure 7 except that they represent cases of annual Aswan spill water equal to $8 \mathrm{BCM}$ and $0 \mathrm{BCM}$ respectively. Table 3 shows the optimized number of days in addition to the daily Toshka spill water and the annual Toshka spill water for different natural river floods and different AHDR levels on $1^{\text {st }}$ of August. 


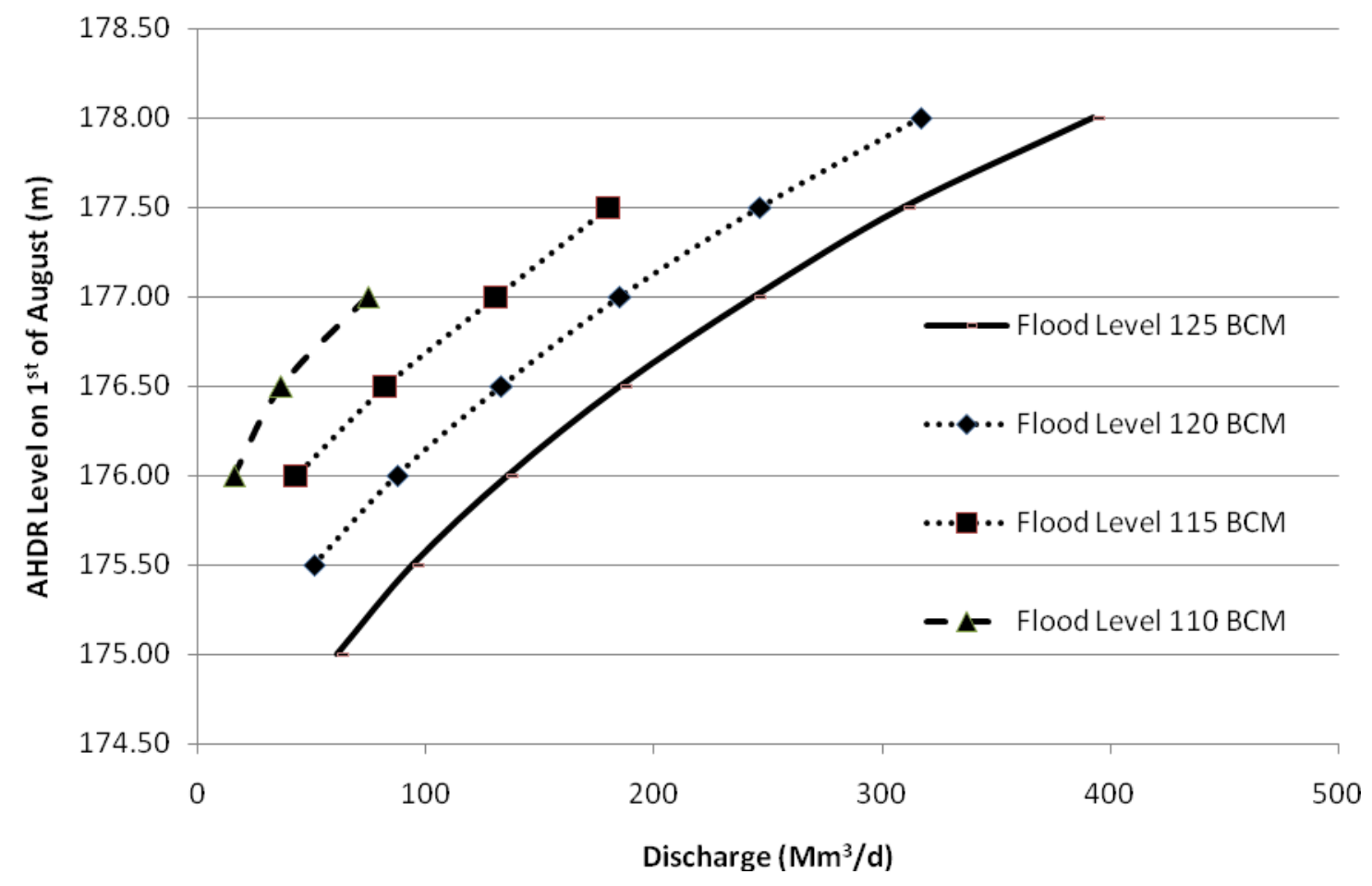

Figure 7: Relationship between the AHDR level and the discharge through the proposed Toshka barrage; Case of 16 BCM annual Aswan spill water. 


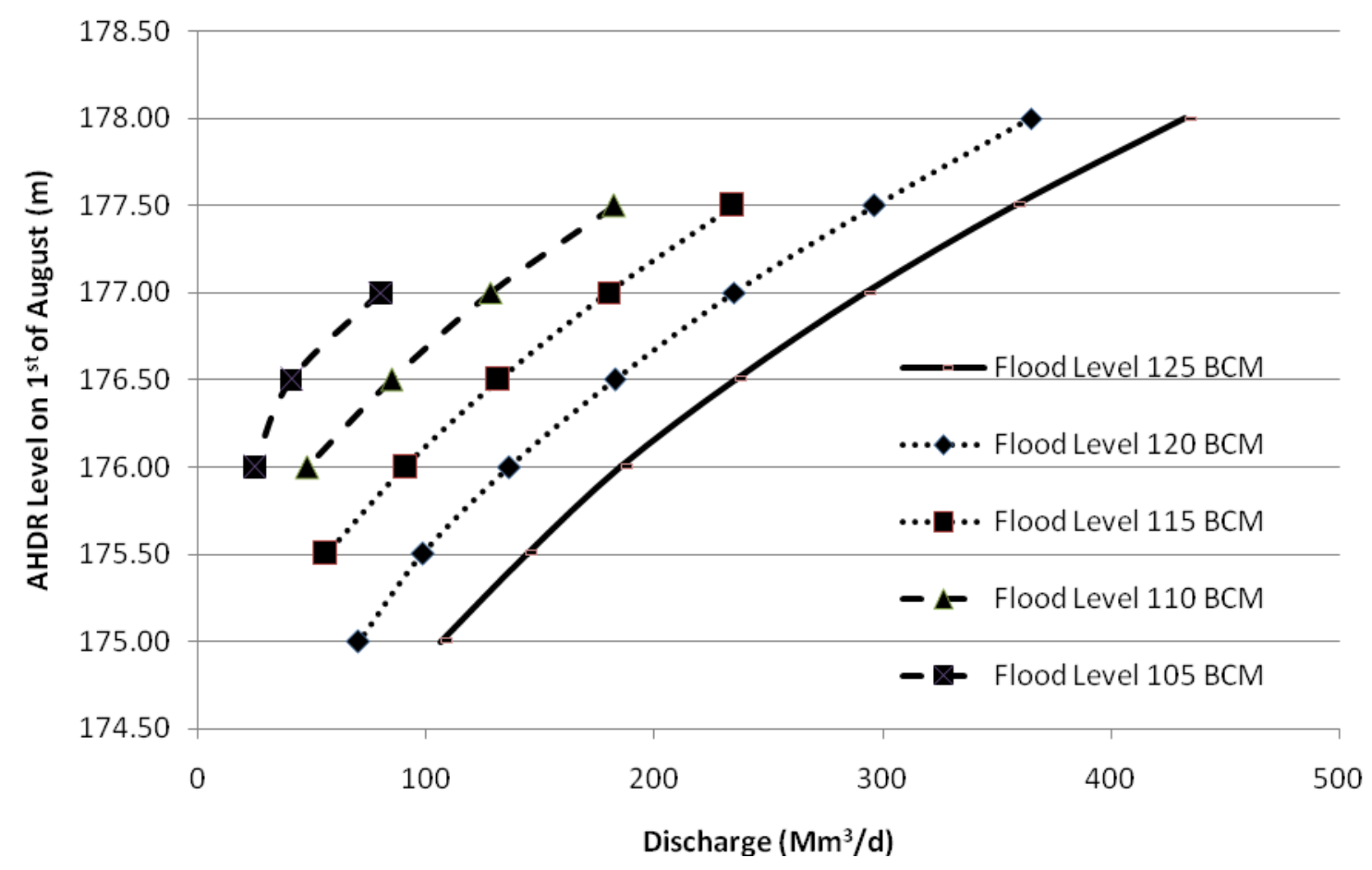

Figure 8: Relationship between the AHDR level and the discharge through the proposed Toshka barrage; Case of 8 BCM annual Aswan spill water.

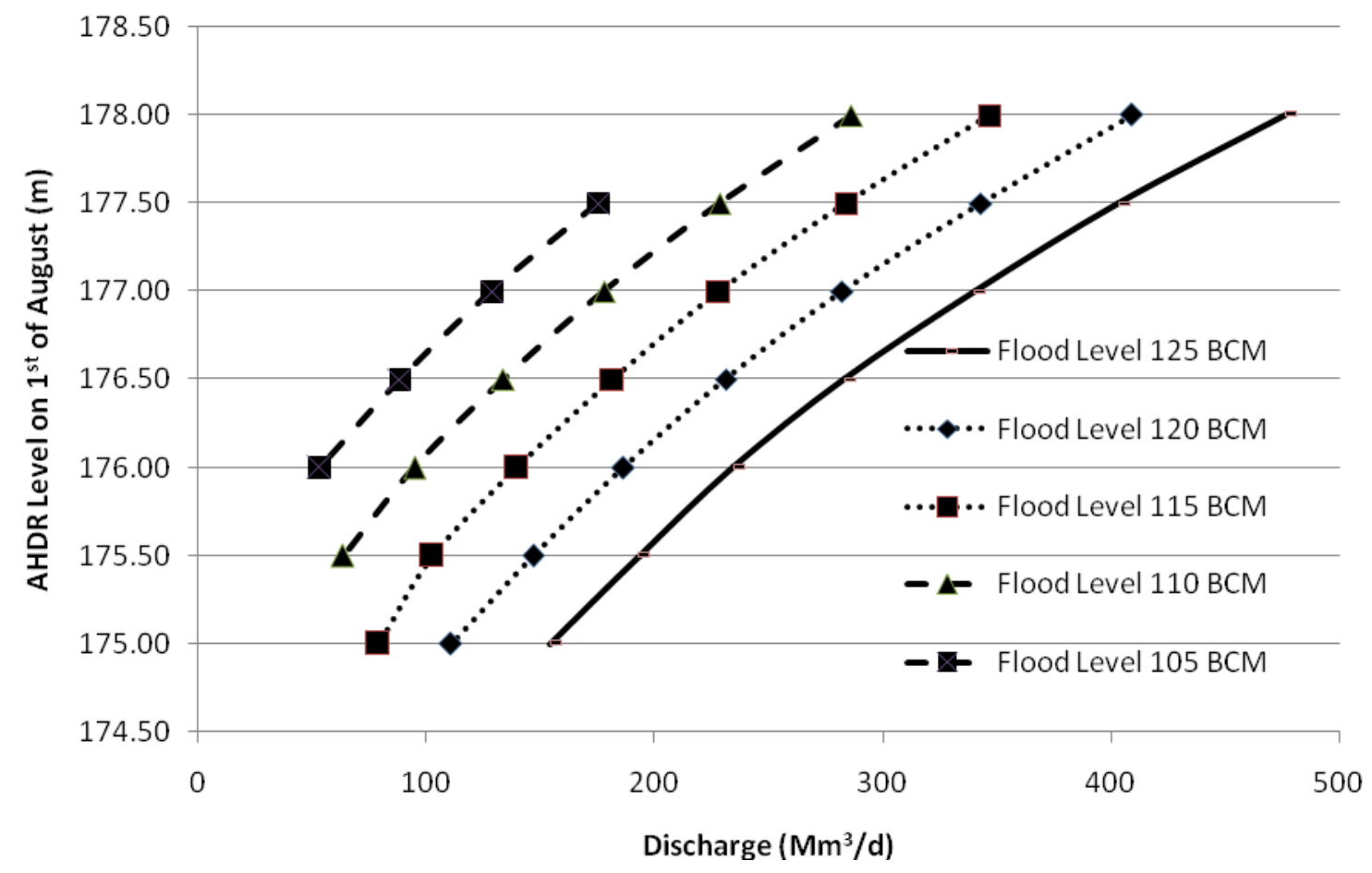

Figure 9: Relationship between the AHDR level and the discharge through the proposed Toshka barrage; Case of 0 BCM annual Aswan spill water. 
Table 3: Optimized number of days, daily Toshka spill water, and annual Toshka spill water for different natural river floods and different AHDR levels on $1^{\text {st }}$ of August.

\begin{tabular}{|c|c|c|c|c|c|c|c|c|c|c|}
\hline \multirow{2}{*}{$\begin{array}{l}\text { W.L. } \\
\text { On 1st } \\
\text { of } \\
\text { August }\end{array}$} & \multirow[b]{2}{*}{$\begin{array}{c}\text { Natural } \\
\text { river } \\
\text { flood }\end{array}$} & \multicolumn{3}{|c|}{$\begin{array}{c}16 \mathrm{BCM} \text { annual } \\
\text { Aswan spill water }\end{array}$} & \multicolumn{3}{|c|}{$\begin{array}{c}8 \mathrm{BCM} \text { annual } \\
\text { Aswan spill water }\end{array}$} & \multicolumn{3}{|c|}{$\begin{array}{c}0 \mathrm{BCM} \text { annual } \\
\text { Aswan spill water }\end{array}$} \\
\hline & & $\begin{array}{c}\text { No } \\
\text { of } \\
\text { days }\end{array}$ & $\begin{array}{c}\text { Daily } \\
\text { Toshka } \\
\text { Spill } \\
\text { Water }\end{array}$ & $\begin{array}{c}\text { Annual } \\
\text { Toshka } \\
\text { Spill } \\
\text { Water }\end{array}$ & $\begin{array}{l}\text { No } \\
\text { of } \\
\text { days }\end{array}$ & $\begin{array}{c}\text { Daily } \\
\text { Toshka } \\
\text { Spill } \\
\text { Water }\end{array}$ & $\begin{array}{c}\text { Annual } \\
\text { Toshka } \\
\text { Spill } \\
\text { Water }\end{array}$ & $\begin{array}{l}\text { No } \\
\text { of } \\
\text { days }\end{array}$ & $\begin{array}{c}\text { Daily } \\
\text { Toshka } \\
\text { Spill } \\
\text { Water }\end{array}$ & $\begin{array}{l}\text { Annual } \\
\text { Toshka } \\
\text { Spill } \\
\text { Water }\end{array}$ \\
\hline meters & $\mathrm{BCM}$ & day & $\mathrm{Mm}^{3} / \mathrm{d}$ & $\mathrm{BCM}$ & day & $\mathrm{Mm}^{3} / \mathrm{d}$ & $\begin{array}{l}\mathrm{BCM} \\
\mathrm{B}\end{array}$ & day & $\mathrm{Mm}^{3} / \mathrm{d}$ & ВCM \\
\hline 178.00 & \multirow{7}{*}{125} & 50 & $392.6 !$ & 19.6 & 64 & 432.5 & 27.7 & 75 & $476.4 '$ & 35.7 \\
\hline 177.50 & & 64 & $309.7 !$ & 19.8 & 78 & 357.4 & 27.9 & 89 & $403.6 !$ & 35.9 \\
\hline 177.00 & & 82 & 244.1 I & 20.0 & 96 & 292.3 & 28.1 & 106 & 340.5 I & 36.1 \\
\hline 176.50 & & 109 & 185.3 & 20.2 & 120 & 235.2 & 28.2 & 128 & 283.1 & 36.2 \\
\hline 176.00 & & 150 & $135.6 !$ & 20.3 & 153 & 185.3 & 28.4 & 155 & 234.6 & 36.4 \\
\hline 175.50 & & 217 & $94.2 !$ & 20.4 & 198 & 143.7 & 28.5 & 189 & 193.0 & 36.5 \\
\hline 175.00 & & 334 & ' ' & 20.4 & 268 & 106.3 & 28.5 & 237 & 154.2 & 36.5 \\
\hline 178.00 & \multirow{7}{*}{120} & 46 & 317.0 & 14.6 & 62 & 365.0 & 22.6 & 75 & 409.2 & 30.7 \\
\hline 177.50 & & 60 & 246.3 & 14.8 & 77 & 296.6 & 22.8 & 90 & 343.1 & 30.9 \\
\hline 177.00 & & 81 & 184.9 ! & 15.0 & 98 & 234.9 & 23.0 & 110 & $282.2 !$ & 31.0 \\
\hline 176.50 & & 114 & 'ו & 15.2 & 127 & 182.5 & 23.2 & 135 & 231.1 & 31.2 \\
\hline 176.00 & & 175 & 87.4 & 15.3 & 171 & 136.3 & 23.3 & 168 & 186.5 & 31.3 \\
\hline 175.50 & & 301 & 50.9 i & 15.3 & 238 & 98.3 & 23.4 & 214 & 146.8 & 31.4 \\
\hline 175.00 & & & ! & & 334 & 70.0 & 23.4 & 284 & 110.7 & 31.4 \\
\hline 178.00 & \multirow{7}{*}{115} & & 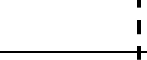 & & & & 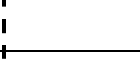 & 74 & 346.6 & 25.6 \\
\hline 177.50 & & 54 & 180.3 & 9.7 & 76 & 234.1 & 17.8 & 91 & $283.9 !$ & 25.8 \\
\hline 177.00 & & 76 & $130.8 !$ & 9.9 & 100 & 179.8 & 18.0 & 114 & 228.2 & 26.0 \\
\hline 176.50 & & 123 & 82.31 & 10.1 & 138 & 131.5 & 18.1 & 144 & 181.7 & 26.2 \\
\hline 176.00 & & 237 & 43.2 i & 10.2 & 201 & 90.9 & 18.3 & 188 & 139.8 & 26.3 \\
\hline 175.50 & & 334 & 31.0 & 10.4 & 327 & 55.8 & 18.3 & 257 & 102.5 & 26.3 \\
\hline 175.00 & & & ! & & & & ! & 334 & 'ו & 26.3 \\
\hline 178.00 & \multirow{6}{*}{110} & & 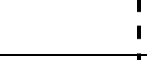 & & & & $\begin{array}{l}1 \\
1\end{array}$ & 72 & י & 20.6 \\
\hline 177.50 & & & i & & 70 & 182.2 & 12.8 & 91 & 228.6 & 20.8 \\
\hline 177.00 & & 66 & 74.5 ' & 4.9 & 101 & 128.2 & 13.0 & 118 & 177.8 & 21.0 \\
\hline 176.50 & & 140 & 36.4 i & 5.1 & 155 & 84.6 & 13.1 & 158 & 133.7 & 21.1 \\
\hline 176.00 & & 334 & 15.7 & 5.2 & 275 & 48.0 & 13.2 & 224 & 94.8 & 21.2 \\
\hline 175.50 & & & 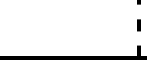 & & & 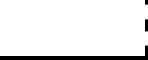 & 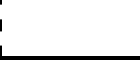 & 334 & 63.5 & 21.2 \\
\hline 177.50 & \multirow{4}{*}{105} & & ! & & & & 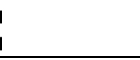 & 90 & 175.2 & 15.8 \\
\hline 177.00 & & & ! & & 99 & 80.0 & 7.9 & 124 & ו' & 15.9 \\
\hline 176.50 & & & 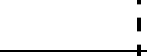 & & 199 & 40.6 & 8.1 & 182 & 88.4 & 16.1 \\
\hline 176.00 & & & ! & & 334 & 24.5 & 8.2 & 303 & $53.2 !$ & 161 \\
\hline
\end{tabular}


Based on the data presented in table 3 and figures 7 through 9, it can be seen that:

- For the maximum probable flood of $125 \mathrm{BCM}$ reported by the authors [5] and for the AHDR level on the $1^{\text {st }}$ of August of 178.00 meters suggested by them [5], the proposed Toshka barrage that is currently under study by the Ministry of Water Resources and Irrigation should pass a spill water of 392.6 $\mathrm{Mm}^{3} / \mathrm{d}, 432.5 \mathrm{Mm}^{3} / \mathrm{d}, 476.4 \mathrm{Mm}^{3} / \mathrm{d}$ for annual Aswan spill water equal to 16 $\mathrm{BCM}, 8 \mathrm{BCM}$, and $0 \mathrm{BCM}$ respectively.

- Since Aswan spill water has an advantage of washing River Nile downstream of Aswan and since some problems regarding covering low levees occurred in 1998/1999 because of high discharges from Aswan, it is recommended that the annual Aswan spill water be only 8 BCM. As a result, the design discharge for the barrage should be at least $450 \mathrm{Mm}^{3} / \mathrm{d}$ (slightly higher than $432.5 \mathrm{Mm}^{3} / \mathrm{d}$ showed in the previous item). The conveyance of the 22 kilometers man made channel connecting the Khor Toshka with the depression should also be increased to $450 \mathrm{Mm}^{3} / \mathrm{d}$. a separate research should be conducted in order to study methods for this conveyance increase.

- If the water level on $1^{\text {st }}$ of August is reduced to 177.00 meters and conserving the flood level at $125 \mathrm{BCM}$, the barrage spill water will be $244.1 \mathrm{Mm}^{3} / \mathrm{d}$, $292.3 \mathrm{Mm}^{3} / \mathrm{d}, 340.5 \mathrm{Mm}^{3} / \mathrm{d}$ for annual Aswan spill water equal to $16 \mathrm{BCM}$, $8 \mathrm{BCM}$, and $0 \mathrm{BCM}$ respectively. This leads to a design discharge of 300 $\mathrm{Mm}^{3} / \mathrm{d}$ for annual Aswan spill water equal to $8 \mathrm{BCM}$ as recommended in the previous item. This reduction of the design discharge from $450 \mathrm{Mm}^{3} / \mathrm{d}$ to 300 $\mathrm{Mm}^{3} / \mathrm{d}$ will save millions of Egyptian pounds required to construct the barrage and increase the channel conveyance. On the other hand, this might cause a problem during periods of drought as the authors explained in their previous research [5]. Detailed studies is required to compare the benefits and the disadvantages of both 177.00 meters and 178.00 meters alternatives with a design discharge of the barrage of 300 and $450 \mathrm{Mm}^{3} / \mathrm{d}$ respectively.

- Data presented in table 3 and figures 7 through 9 defines the operation rules of the proposed barrage for different natural river floods as the barrage should pass the shown daily discharges for the shown number of days staring from $1^{\text {st }}$ of September when the prediction defines the natural river flood value.

\section{SUMMARY AND CONCLUSIONS}

- A water balance model has been performed for the Aswan High Dam Reservoir based on the conservation of mass. The objective for this water balance model is to assess the capability of the AHDR to sustain high floods under the condition that the reservoir is full. 
- In order to perform the water balance, data for the Aswan High Dam reservoir were collected, inspected and used for the periods when the reservoir is in full or near full conditions. These periods covers four water years from August 1998 to July 2002.

- Used data covers reservoir levels, level-area-contents relationship, evaporation, natural river flows, Sudanese share, Egyptian share, Aswan Spill water, and Toshka spill water.

- Using the measured data for the Toshka weir, a model for releases from the weir was obtained. This model succeeded in calculating the Toshka spill water during the year 1998/1999 and 1999/2000. The model failed to calculate the Toshka spill water during the year 2000/2001 and 2001/2002 because of the manual control of the releases during that years.

- Model for the bank storage, regional flow, and seepage was obtained, calibrated and verified.

- The Aswan High Dam Reservoir water balance was used in order to assess the capability of the current weir to sustain different natural river floods under different levels of AHDR on $1^{\text {st }}$ of August with different values of annual Aswan spill water.

- It was concluded that if the water level on $1^{\text {st }}$ of August is raised to 178.00 meters as the authors recommended in a previous research, the weir will sustain only 103.3 BCM flood under the condition of annual Aswan spill water equal to $16 \mathrm{BCM}$. Since the maximum probable flood as reported by the authors is $125 \mathrm{BCM}$. The weir will fail to sustain this flood with a level of AHDR of 178.00 meters.

- Replacing the current weir of Toshka by a barrage is currently under study in the Ministry of Water Resources and Irrigation. This research defined that the proposed barrage should has a design discharge of at least $450 \mathrm{Mm}^{3} / \mathrm{d}$ if the AHDR level on $1^{\text {st }}$ of August is 178.00 meters while it should be $300 \mathrm{Mm}^{3} / \mathrm{d}$ if the AHDR level on $1^{\text {st }}$ of August is 177.00 meters.

- Detailed studies is required to compare the benefits and the disadvantages of both 177.00 meters and 178.00 meters alternatives with a design discharge of the barrage equal to $300 \mathrm{Mm}^{3} / \mathrm{d}$ and $450 \mathrm{Mm}^{3} / \mathrm{d}$ respectively.

\section{REFERENCES}

1. Emam, M.M., 2001, "Dynamics of Optimum Operation of Nasser Lake for Maximum Benefit from High and Low Floods", M. Sc. Thesis, Ain Shams University, Cairo, Egypt, 2001.

2. High Aswan Dam Authority, 1976, "Studies and Researches of Toshka Spillway Project", Research Project \# 3, Aswan, January 1976, Part I and II.

3. http://www.ilec.or.jp/database/afr/afr-19.html, International Lake Environment Committee web page 
4. Hurst, Black, and Simaika, "The Major Nile Projects", The Nile Basin, Vol. $\mathrm{X}$.

5. Kotb, M. E.; Mehanna, A.E., Khadr, W., 2010, "Statistical Analysis for Low and High River Nile Flood", $7^{\text {th }}$ International Engineering Conference, Faculty of Engineering, Mansoura University, 23-28 March 2010.

6. Linsley, R.K.; Franzini, J.B., Freyberg, A.L.; and Tchobanoglous, G., "Water Resources Engineering", McGraw-Hill, Inc., ISBN 0-07-038010-4, 1992.

7. Master Plan for Water Resources Development and Use, 1981, "Hydrological Simulation of Lake Nasser", Technical report No. 14, Vol. I and II.

8. Mostafa, E.A., 1998, "Flow in a Channel Connecting Two Reservoirs; Case Study: Toshka Channel Connecting Between Aswan Reservoir and Toshka Depression”, Conference on Coping With Water Scarcity, Hurghada, Egypt, 26-28 August, 1998.

9. Shahin, M., "Developments in Water Science, 21, Hydrology of the Nile Basin”, Elsevier Science Publishers B.V., ISBN 0-444-42433-4, 1985. 